\title{
Heterozygous truncating mutation in the human homeobox gene GSH2 has no discernable phenotypic effect
}

\author{
J G Dauwerse, C E M de Die-Smulders, E Bakker, M H Breuning, D J M Peters
}

J Med Genet 2002;39:686-688

M utations in transcription factors with homeobox domains have been identified in a number of developmental disorders, for instance, mutations in PAX6 have been identified in patients with aniridia, mutations in $\mathrm{HOX}_{13}$ in patients with synpolydactyly, and mutations in MSX2 in patients with Boston-type craniosynostosis.

The mouse GSH2 gene, like the related GSHI gene, encodes a homeodomain containing gene that is homologous to the Drosophila intermediate neuroblasts defective (ind) gene. ${ }^{2}$ In situ hybridisation of GSH2 showed a dynamic, developmentally regulated, spatial and temporal expression pattern. ${ }^{3}$ Transcripts are particularly abundant in the hindbrain and in the ventral domain of the forebrain. ${ }^{3}$ GSH2 is a downstream target of sonic hedgehog $(\mathrm{SHH})$ and is probably a key regulator in downstream SHH patterning in the ventral forebrain. Mice lacking GSH2 show profound defects in telencephalon development. ${ }^{4}$ Comparing mice lacking functional alleles of either GSH2 or PAX6 indicated complementary roles for these two genes in dorsoventral patterning of the telencephalon. ${ }^{5}$

\section{METHODS}

In a search for a developmental gene on chromosome 4q12, we identified the human homologue of the GSH2 gene. To do so, we performed inter-Alu PCR on yeast artificial chromosome clone $303 \mathrm{~b} 3$ (CEPH megaYAC ${ }^{6}$ ) that by FISH was mapped to the chromosome $4 \mathrm{q} 12$ region. With these PCR products, we isolated cosmid $232 \mathrm{Gl} 2$ from a chromosome 4 cosmid library ${ }^{7}$ and PAC clones pDJ194i7 and pDJ200G9 from the RPCl PAC library. ${ }^{8}$ The sequences initially generated on fragments of the cosmid showed homology with BAC clone RP11-56d20, a clone partially sequenced by the Whitehead Institute/ MITcenter. The NIX program at www.hgmp.mrc.ac.uk, which is a tool to identify unknown nucleic acid sequences, was used to analyse the partial sequences of the BAC clone, suggesting the presence of (part of) a gene homologous to mouse GSH2 (swissprot P31316) and GSHl proteins, and identified the human platelet derived growth factor receptor $\alpha$ (PDGFRA) gene (GenBank XM011186). The mouse GSH2 gene (GenBank S79041) is located in the syntenic region on mouse chromosome 5. Blast searches at the NCBI (http:// www.ncbi.nlm.nih.gov) showed homology with a large number of small ESTs (for example, A1005406, Al360912, Al797226, AA485189) and, indeed, these clones hybridised to cosmid 232G12. Subclones of this cosmid were used to obtain the complete genomic sequence, which was submitted to GenBank (AF439445). We sequenced the gene four times, including sequences obtained on genomic DNA. The GSH2 gene contains a predicted ORF of $915 \mathrm{bp}$ encoding a protein of 304 amino acids. The gene consists of two coding exons with a $651 \mathrm{bp}$ intron in between. Exon 1 consists of 575 bp coding sequence and the size of the $5^{\prime}$ UTR is not known, exon 2 consists of 340 bp coding sequence and 239 bp 3'UTR. Recently, a coding sequence has also been published in GenBank
(AH010253). The putative translation start site, 5'CUCGACAUGU-3', at position 310 in our sequence is not accompanied by a typical Kozak sequence. A consensus polyadenylation signal (5'-AATAAA-3') was observed 553 bp after the stop codon. In contrast to mouse GSH2, which contains two polyadenylation signals close to each other, the human gene has only one.

\section{RESULTS}

The deduced amino acid sequence of human GSH2 and the sequences of mouse GSH2 and GSHl are presented in fig 1. Sequence comparison with mouse GSH2 showed that the genes are highly conserved between mouse and human, with $89 \%$ identity and $91 \%$ similarity over the entire ORF. Most of the non-identical amino acids are located between residues 75 and 100 , a region that is absent in mouse GSHI. In addition, the protein is homologous to mouse GSHl (GenBank NM_008178). The 57 amino acid sized homeodomain, which is involved in DNA binding, is entirely conserved.

\section{DISCUSSION}

In an effort to identify a gene involved in acrodysostosis and short stature, we performed single strand conformation polymorphism analysis (SSCA) in a set of short stature patients and controls. Primers were selected to amplify the exons with adjacent splice sites and branch sites in six overlapping fragments (table 1). The products were separated on $10 \%$ non-denaturing polyacrylamide gels (49:1, acryamide:bis acrylamide) with and without glycerol and on $0.5 *$ sequagel $\mathrm{MD}$ gels (7-15 $\mathrm{W}$ for \pm 16 hours at room temperature)

\section{Key points}

- The mouse GSH2 (genomic screened homeobox-2) gene is a homeobox domain containing transcription factor with a developmentally regulated expression pattern. Mice lacking GSH2 show profound defects in telencephalon development.

- We describe the cloning, identification, and sequencing of the human homologue of the GSH2 gene. The gene consists of two exons and the 915 bp open reading frame (ORF) encodes a protein of 304 amino acids. The human GSH2 protein is highly conserved with $89 \%$ identity and $91 \%$ similarity with mouse GSH2.

- In a father and daughter without a discernable developmentally aberrant phenotype, we identified a truncating mutation in the homeobox domain. These data indicate that, unlike most disease associated transcription factors, loss of one functional copy of GSH2 does not result in a disease phenotype. 
MGSH1

182 YLNLSEKQVKIWFQNRRVKHKKEGKGSNHRGGAGAGAGGGAPQGCKCSSLSSAKCSEDDD

MGSH2 239 YLNLSEKQVKIWFQNRRVKHKKEGKGASRN- - - - - - - NHTSCKCVG-SQAHYARSED

HGSH2 238 YLNLSEKOVKIWFONRRVKHKKEGKGTORN---------SHAGCKCVG-SOVHYARSED

$\begin{array}{lll}\text { MGSH1 } & 242 & \text { ELPMSPSSSGKDDRDLTVTP } \\ \text { MGSH2 } & 288 & \text { EDSLSPASAN-EDKEISPL- } \\ \text { HGSH2 } & 287 & \text { EDSLSPASAN-DDKEISPL- }\end{array}$

Figure 1 Alignment of the amino acid sequences of mouse GSH1, GSH2, and human GSH2. Human GSH2 (GenBank AF439445) is aligned to mouse GSH2 (SwissProt P31316) and mouse GSH1 (GenBank NM_008178). Most differing amino acids between human and mouse GSH2 are between AA 75 and 100. The homeobox domain is indicated by an underline. The nonsense mutation, Glu220X, is indicated by an asterisk. The mutation is designated according to the recommendations of Antonarakis et al. ${ }^{10}$

\begin{tabular}{|c|c|c|c|c|c|c|}
\hline \multicolumn{2}{|c|}{ Primer name } & \multirow{2}{*}{$\begin{array}{l}\text { Sequence }\left(5^{\prime}-3^{\prime}\right) \\
\text { GAGCACCTTGCCCGAGCCTTACC } \\
\text { CTCCTTGTCATCGTTGGCTGAGG }\end{array}$} & \multirow{2}{*}{$\begin{array}{l}\text { Position } \\
1496-1518 \\
1838-1860\end{array}$} & \multirow{2}{*}{$\begin{array}{l}\text { Fragment } \\
\text { size }\end{array}$} & \multirow{2}{*}{$\begin{array}{l}\begin{array}{l}\text { Annealing } \\
\text { temp }\end{array} \\
56\end{array}$} & \multirow{2}{*}{$\begin{array}{l}\begin{array}{l}\text { PCR } \\
\text { buffer }\end{array} \\
\text { A }\end{array}$} \\
\hline Gsh12 & $\begin{array}{l}\mathrm{F} \\
\mathrm{R}\end{array}$ & & & & & \\
\hline Gsh13 & $\begin{array}{l}\mathrm{F} \\
\mathrm{R}\end{array}$ & $\begin{array}{l}\text { TCCGAGGATGAGGACTCCCTGTC } \\
\text { CCCCATACAGTGTTAAACTTAA }\end{array}$ & $\begin{array}{l}1810-1832 \\
2159-2180\end{array}$ & $370 \mathrm{bp}$ & 56 & A \\
\hline Gsh 14 & $\begin{array}{l}F \\
R\end{array}$ & $\begin{array}{l}\text { CAACTCATTCTTGTCGTATAAC } \\
\text { GCAGGAGAAGATAGGGAGAGCAA }\end{array}$ & $\begin{array}{l}2117-2138 \\
2159-2180\end{array}$ & $374 \mathrm{bp}$ & 55 & B \\
\hline Gsh 15 & $\begin{array}{l}\mathrm{F} \\
\mathrm{R}\end{array}$ & $\begin{array}{l}\text { AGGGCAGAGCTTAGAACACTAGA } \\
\text { AGTGCAGGTGCGAAGTGAC }\end{array}$ & $\begin{array}{l}234-256 \\
502-520\end{array}$ & $286 \mathrm{bp}$ & 56 & $A^{*}$ \\
\hline Gsh16 & $\begin{array}{l}\mathrm{F} \\
\mathrm{R}\end{array}$ & $\begin{array}{l}\text { CCATTGGTGATGTCCGTGT } \\
\text { CTGATGATGGTGATGGTGGT }\end{array}$ & $\begin{array}{l}427-445 \\
710-729\end{array}$ & $302 \mathrm{bp}$ & ND & ND \\
\hline Gsh17 & $\begin{array}{l}F \\
R\end{array}$ & $\begin{array}{l}\text { GTGAACCATGCGCATCATC } \\
\text { AAAGGCGCGGAGCGCAGGTG }\end{array}$ & $\begin{array}{l}673-691 \\
903-922\end{array}$ & $249 \mathrm{bp}$ & 56 & $A^{*}$ \\
\hline
\end{tabular}

essentially according to the protocols described by Orita et al. ${ }^{9}$ In a family where the index case had short stature and mental retardation, we identified in the father and sister with "normal" phenotypes, a G to T transition at position 658, changing a glutamine into a stop. This mutation, which was not present in the index patient, is predicted to truncate the protein at amino acid 220, within the homeobox domain of the gene (fig l). We do not know whether this mutation generates a stable truncated protein. If it does, the truncated protein does not have a dominant negative affect on the function of the full length protein, probably because the mutation is in the beginning of the homeodomain. Apparently, loss of one functional copy of GSH2 has no discernable phenotypic effect. For most disease associated transcription factors, haploinsufficiency results in the disease phenotype, indicating that gene dosage is critical at specific time points in development. This high degree of dosage sensitivity often appears to affect only a subset of tissues that express the gene. ${ }^{1}$ Our data are in agreement with the observation that heterozygous $\mathrm{GSH}^{++-}$mice seem to be indistinguishable from wild type mice and have a normal life span. ${ }^{3}$

GSH2 contains a polyalanine stretch of 16 residues. Polyalanine tracts are common in homeobox genes and in other transcription factors. For several of these genes, inactivation by polyalanine tract expansion has been shown to cause a disease phenotype as, for example, in HOXAl3 involved in the hand-foot-genital syndrome ${ }^{11}$ or HOXD13 involved in synpolydactyly. ${ }^{12}$ In these genes the expansions are short, are meiotically stable, and are probably caused by unequal crossing over during replication, thus being different from other unstable pathological trinucleotide expansions. ${ }^{11}$ In GSH2, the polyalanine tract is not encoded by a perfect triplet repeat and, indeed, in 200 unrelated chromosomes we did not observe a repeat expansion. 
It can be concluded that GSH2 is a highly conserved gene and that a heterozygous truncating mutation does not cause a discernable phenotype.

\section{ACKNOWLEDGEMENTS}

We thank P Taschner (LUMC) for assistance in NIX analyses, M Losekoot for DNA samples, and M van de Berg (Leiden Genome Technology Centre) for screening the PAC library.

\section{Authors' affiliations}

J G Dauwerse, E Bakker, M H Breuning, D J M Peters, Center of Human and Clinical Genetics, Leiden University Medical Centre, The Netherlands

C E M de Die-Smulders, Department of Clinical Genetics, Academic Hospital Maastricht, The Netherlands

Correspondence to: Dr D J M Peters, Center of Human and Clinical Genetics, Leiden University Medical Centre, Sylvius Laboratory,

Wassenaarseweg 72, 2333AL Leiden, The Netherlands;

d.j.m.peters@lumc.nl

\section{REFERENCES}

1 Engelkamp D, van Heyningen V. Transcription factors in disease. Curr Opin Genet Dev 1996:6:334-42.

2 Weiss JB, Von Ohlen T, Mellerick DM, Dressler G, Doe CQ, Scott MP. Dorsoventral patterning in the Drosophila central nervous system: the intermediate neuroblasts defective homeobox gene specifies intermediate column identity. Genes Dev 1998;12:3591-602.
3 Szucsik JC, Witte DP, Li H, Pixley SK, Small KM, Potter SS. Altered forebrain and hindbrain development in mice mutant for the Gsh-2 homeobox gene. Dev Biol 1997; 191:230-42.

4 Corbin JG, Gaiano N, Machold RP, Langston A, Fishell G. The Gsh2 homeodomain gene controls multiple aspects of telencephalic development. Development 2000; 127:5007-20.

5 Yun K, Potter S, Rubenstein JL. Gsh2 and Pax6 play complementary roles in dorsoventral patterning of the mammalian telencephalon. Development 2001;28: 193-205.

6 Cohen D, Chumakov I, Weissenbach J. A first-generation physical map of the human genome. Nature 1993;366:698-701.

7 Riess O, Siedlaczck I, Kredtke S, Melmer G, Epplen JT, Deaven LL. Characterization of a human chromosome 4 flow-sorted cosmid library. Cytogenet Cell Genet 1994;65:238-42.

8 loannou PA, Amemiya CT, Garnes J, Kroisel PM, Shizuya H, Chen C Batzer MA, de Jong PJ. A new bacteriophage P1-derived vector for the propagation of large human DNA fragments. Nat Genet 1994;6:84-9.

9 Orita M, Iwahana H, Kanazawa H, Hayashi K, Sekiya T. Detection of polymorphisms of human DNA by gel electrophoresis as single-strand conformation polymorphisms. Proc Natl Acad Sci USA 1989:86:2766-70.

10 Antonarakis SE. Recommendations for a nomenclature system for human gene mutations. Nomenclature Working Group. Hum Mutat 1998;11:1-3.

11 Goodman FR, Bacchelli C, Brady AF, Brueton LA, Fryns JP, Mortlock DP, Innis JW, Holmes LB, Donnenfeld AE, Feingold M, Beemer FA, Hennekam RC, Scambler PJ. Novel HOXA 13 mutations and the phenotypic spectrum of hand-foot-genital syndrome. Am J Hum Genet 2000;67:197-202.

12 Muragaki Y, Mundlos S, Upton J, Olsen BR. Altered growth and branching patterns in synpolydactyly caused by mutations in HOXD 13 Science 1996;272:548-51.

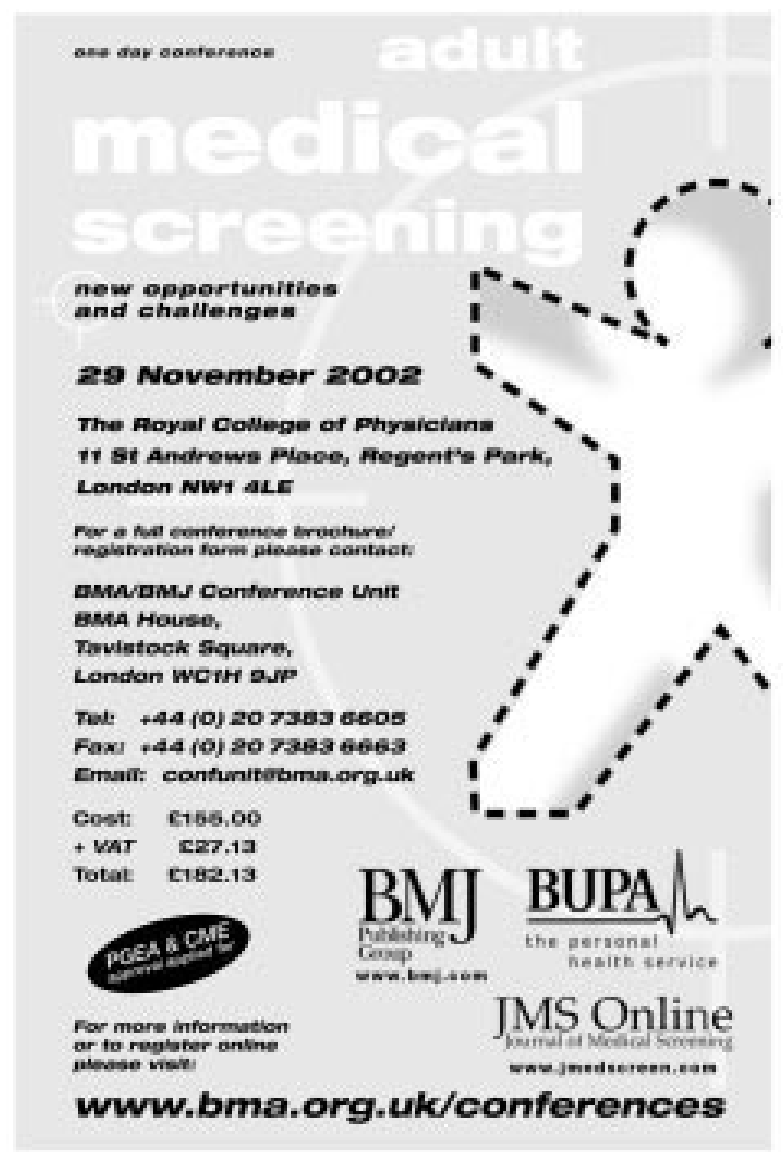

